\title{
Twins in My Cradle: Arthur Davison Ficke, Iowa Poet
}

\author{
W I L L I A M H. R O B A
}

It seems appropriate to review the life and career of Arthur Davison Ficke (1883-1945) in the centennial year of his birth. During the first half of the twentieth century, Ficke's fame seemed secure. For many writers, he was a poet's poet. Theodore Dreiser enjoyed Ficke's company because of his "seemingly changeless poetic response to life,-lovely though sombre or gay moods or emotions that appear to me to bubble or sweep upwards to expression - as water rises over grass and moss in a dell or over the hard rocks and hot sands of a desert..." ${ }^{\prime 1}$ His poetry appeared in the first issues of Poetry and the Little Review, and in the first volumes of Midland and the Saturday Review of Literature. In addition, his interpretation of Japanese painting enjoyed an international reputation and his humorous poetry graced the pages of the early Esquire.

His early success can be explained in part by the support of his family. Both his father and his mother encouraged him towards a public career in literature. His father, Charles A. Ficke, was the richest man in eastern lowa and a political leader of the German community in Davenport. ${ }^{2}$ C. A. Ficke had been born in Germany, though his wife, Frances Ficke, had grown up in the village of East Davenport. Her father was a prominent attorney who welcomed the young German-American into the city's legal fraternity. Frances served on the Davenport Public Library board of trustees for 36 years and remained active in the Unitarian Church, where young Arthur went to Sunday school. Both parents continued their intel-

\footnotetext{
${ }^{1}$ Dreiser to ADF, August 12, 1933. Letters of Theodore Dreiser: A Selection, ed. Robert H. Elias (Philadelphia: University of Pennsylvania Press, 1959), 2:637.

${ }^{2}$ There is an autobiographical work by Arthur's father: Charles August Ficke, Memories of Fourscore Years [Davenport: Graphic Services, 1930]. Of the father-son relationship John Cowper Powys remarked that "I have a peculiar and natural sympathy with Arthur, because he, like myself, has long been dominated by a formidable begetter, whose personality excited in his son a mixture of respect, awe, furious rebellion, and inarticulate affection." J. C. Powys, Autobiography (London: Macdonald, 1967), 609.
} 
lectual pursuits by forming discussion groups: Charles cofounded the Contemporary Club of Davenport, and Frances was a charter member of the Tuesday Club. ${ }^{3}$

In the fall of 1896 when Arthur Ficke enrolled in Davenport High School as a freshman, no one doubted that he was headed towards a literary career. He joined the Adelphian Society, a debating club that mixed oratory and parties, and was eventually elected president of the club. In his senior year he became literary editor of the Red and Blue, the high school newspaper. That fall he published five poems, two essays, and two short stories in the newspaper. ${ }^{4}$ He had followed the Classical curriculum, graduating in a class of 69 in May 1900 at the recently finished Turner Grand Opera House.

For the next four years Ficke enjoyed college life at Harvard. He studied under William James and George Santayana and became friends with Witter Bynner, an upperclassman who reinforced his intention of becoming a published poet. Ficke wrote for the Advocate, one of the college's literary magazines, serving as president his senior year.

After graduation from Harvard, Ficke joined his family on a ten-month trip around the world. While waiting for a launch near Bombay, India, Ficke spent two days enjoying the company of Maurice Browne, an English school teacher. As Browne recalled the encounter, "The American claimed to be a lawyer, Maurice to be a schoolmaster. Convention satisfied, the American quoted Keats; Maurice capped him with Shelley. Five minutes later the truth could no longer be hid; they were poets." ${ }^{5}$ When Browne returned to England, he established in Surrey the Samurai Press, which published Ficke's early collection of poems From the Isles (1907), inspired by his world-circling trip.

Ficke spent two years, 1906 and 1907, at The University of Iowa studying for a law degree and teaching in the English department. ${ }^{6} \mathrm{He}$ then joined his father's law firm and the Contemporary Club, whose

\footnotetext{
${ }^{3}$ Davenport Democrat, December 10,1931, and September 23, 1945. A psychological perspective appears in Ted Stichnoth, "A Contrary Vision: The Roots of Alienation in Davenport," undergraduate honors thesis (Yale, 1973).

${ }^{4}$ Red and Blue, issues for June, September, October, and November 1899 and January 1900.

${ }^{5}$ Maurice Browne, Too Late to Lament (Bloomington: Indiana University Press, 1956), 78. Browne's influence in Chicago is described by Clarence Andrews, Chicago in Story: A Literary History (Iowa City: Midwest Heritage Pub. Co., 1982), 128-29.

${ }^{6}$ His lecture notes for a course on the Arthurian legend are preserved in The University of Iowa Libraries. Some 20 years later his recollection of his students was rather astringent: "I was greatly struck by the almost total absence of intellectual curiosity or of intelligent interests among the students. Conversation on art, literature, philosophy, or science was wholly unknown: to talk of such things stamped a student as a "highbrow" and was regarded as a contemptible affectation. ..." ADF to Lucile Morsch, editor of the Iowa Literary Magazine, August 19, 1926, Special Collections, The University of Iowa Libraries.
} 
members welcomed him at their monthly meetings. ${ }^{7}$ On October 1 , 1907, he married Evelyn B. Blunt in Springfield, Massachusetts, in a ceremony described in the local newspaper as a "brilliant Episcopalian nuptial event." 8 During the next ten years, Ficke balanced precariously the life of a Davenport corporate lawyer, happily married and carrying on an upper-class social life, with the exciting life of a visiting poet in Chicago.

The strain that was beginning to show in Ficke's balanced world, however, was noted by Maurice Browne, who visited his friend in Davenport in 1912. "Legal duties intervened; poetry was sandwiched between social engagements; in the middle of a lyric my hostess would summon her husband. He was witty, handsome, debonair; she was correct, beautiful, charming ..." As the years went on, the strain became difficult to handle.

Chicago beckoned to him "and Ficke found that the legal affairs of his father's firm necessitated long visits at short intervals to Chicago." ${ }^{10}$ After arriving on the Golden State passenger train at La Salle Street Station, Ficke would check into the Blackstone and plan his weekend. A close friend, Eunice Tietjens, especially welcomed him because "when he came we had lunches and dinners at the choicest restaurants, ordered with a nicety of understanding of the graces of the table and of fine wines." ${ }^{11}$ Setting off his elegant manners, Ficke was an impeccable dresser, and the tall poet stood out in the bohemian mixture of newspaper reporters and young poets that constituted the more typical literary parties in Chicago.

At first it must have been enjoyable for Ficke to have the best of two possible worlds, the haut monde of Davenport and the experimental partying of bohemian Chicago. This regimen also allowed Ficke to enjoy a number of platonic relationships. The most important of these was his lifelong friendship with Edna St. Vincent Millay. It began on Thanksgiving Day 1912, while his Harvard friend Witter Bynner was visiting. Bynner was clutching a brand new book of poetry, Lyric Year, and "as they were walking home from his [Ficke's] law office, Bynner . . came upon [Millay's] 'Renascence' and was so moved by this work that he felt he must read it to his fellow poet. They sat down at the base of the Soldier's Monument and there... Bynner read the

\footnotetext{
${ }^{7}$ His maiden essay was delivered on October 1, 1908. See "Injunctions against Labor," Contemporary Club Papers 14 (1908-9): 1-18.

${ }^{8}$ Davenport Democrat, October 2, 1907.

${ }^{9}$ Browne, Too Late to Lament, 113.

${ }^{10}$ Ibid., 131.

${ }^{11}$ Eunice Tietjens, The World at My Shoulder (New York: Macmillan, 1938), 58. Their friendship is documented by a series of undated letters in the Newberry Library concerning luncheon plans and meeting times when Ficke would be in Chicago.
} 


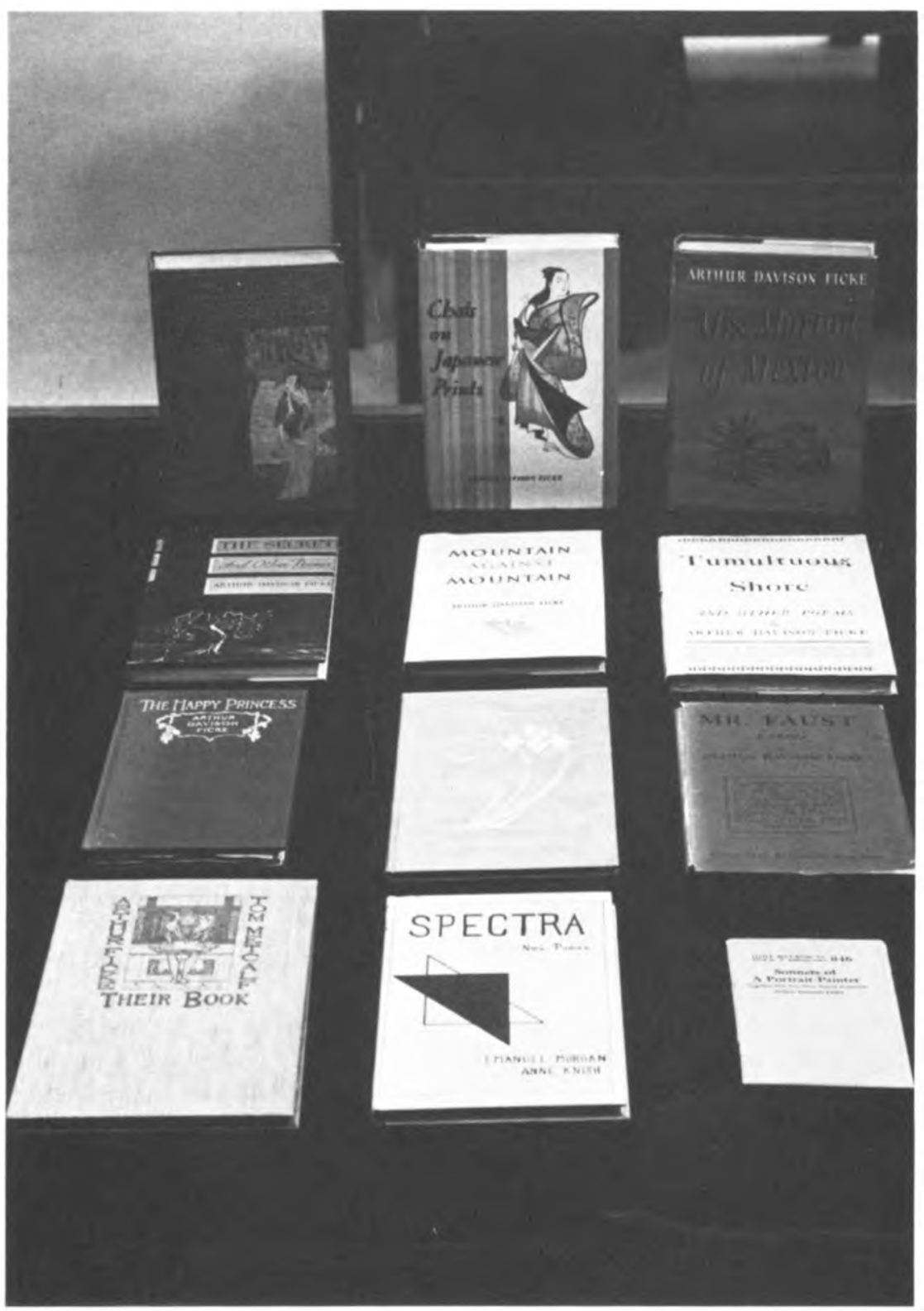

Twelve books by Arthur Davison Ficke (1883-1945) of Davenport, lowa, selected from some forty of his publications presently on the shelves of the lowa Authors Collection. 
poem aloud."12 At the end of the year, Ficke wrote to Miss Millay, sending her a paperback copy of Blake's poetry. This was the beginning of a series of flirtatious letters written by "Vincent," as she liked to be called. By the middle of the next year, she called him her "Spiritual Advisor"; in a year's time she teased him in the following way: "Go to!-Would you have me write you an improper letter?-Upon my soul I half believe you would! And I am not yet so Vassarized but that such a thing is still possible. But I should never send it, you know,-so what would be the use?"13

Ficke's growing frustration comes through in his correspondence with Floyd Dell, a sometime Davenporter who had broken away from the stifling influences of family and friends and moved to Chicago in 1909. In these personal notes, criticism of Davenport's leading light, Alice French, is quite marked: "It will amuse you to know that at Miss French's talk, - which, after all, I did not attend,- - the Right Reverend Theodore N. Morrison, Episcopal Bishop of lowa, arose at the end of her remarks, and in the name of the churches, past, present and to come, flatly contradicted every word she had said." 14 Particularly upsetting were Dell's descriptions of bohemian parties that Arthur was unable to attend. "Gawd, how I wish I'd been at Elaine's at your org[y]. It would have been distressing if my well-known integrity had forced me to take issue with you when you adduced fal[1]acious arguments to prove me a grt. pote." 15

For the next two years, Ficke was content to continue writing his poetry while living in Davenport. He kept his humorous poetry unpublished, while concentrating on traditional forms of poetry, especially the sonnet. In February 1916, the delicate balance began to tilt towards the "lit'ry life." His friend Bynner arrived from Chicago, upset with the Imagist school of poetry and ready to attempt a satirical jab at that group. Along with Marjorie Allen Seiffert, who lived across the Mississippi River in Moline, Illinois, these three friends concocted a fanciful group of experimental poets called the "Spectric" school, named after the ballet "Spectre de la Rose" that Bynner had attended in Chicago. They proceeded to produce poems based on their subconscious thoughts. "Sometimes we would start with an idea, sometimes with only a phrase, but the procedure was to let all reins go, to give the idea or the phrase complete head, to take whatever road or field or fence it chose." ${ }^{16}$ The

\footnotetext{
${ }^{12}$ Letters of Edna St. Vincent Millay, ed. Allan Ross Macdougall (New York: Harper's 1952), 18.

${ }^{13}$ Ibid., 48.

${ }^{14}$ ADF to Floyd Dell, February 1, 1913, Newberry Library.

${ }^{15}$ ADF to Floyd Dell, April 14, 1913, Newberry Library.

${ }^{16}$ Witter Bynner, "The Story of the Spectric School of Poetry," Palms, 5, no.6 (March 1928): 208. See also William Jay Smith, The Spectra Hoax (Middletown, Connecticut: Wesleyan University Press, 1961).
} 
result was enough poems to submit for publication. Ficke declared that "it was only Bynner's opportune departure ... that prevented us from becoming seriously interested in further and genuine experiments. . . ."17

In June a theoretical article on the "Spectra school" appeared in the Forum, no doubt with the knowing connivance of the editor, Mitchell Kennerley. In an oblique reference to the Surrealist manifesto of André Breton, Ficke described the new type of Spectric poet as one who believed that "the apparently unrelated impressions reflecting through a theme or idea may be artfully enough selected or directly enough recorded, without the conventional mental or verbal bridges, to reproduce, in the reader's mind, their effect on the mind of the poet." ${ }^{18}$ In emphasizing a "heightened" reality, the Spectric manifesto of Ficke and Bynner laid down these precepts: if the poet "wishes to describe a landscape, he will not attempt a map, but will put down those winged emotions, those fantastic analogies, which the real scene awakens in his own mind." 19 When serious criticism of Spectric poetry began to appear, "the two original Spectrists were elated and tossed dice to determine who should have permanent possession of the letter. Bynner won and Ficke thereupon had a copy certified by a notary public to convince anyone to whom he showed his files that the praise of the serious-minded poet was genuine." 20 Their bubble burst when the Dial described the Spectric process and stated that "the interruption of the war ... gave 'Miss Knish' a commission as Captain Arthur Davison Ficke." ${ }^{21}$ After the war, Bynner was quoted as saying Ficke had told him with "a distinct note of grief in his voice: 'Do you know, some of my best work is in 'Spectra'?"22

From 1917 to 1922, wartime conditions gave Ficke an opportunity to change his routine. While the Spectric hoax slowly unraveled, Ficke volunteered for service. His father-in-law, Colonel Stanhope Blunt, influenced this decision along with the pro-American stance of his father. The Davenport newspapers publicized his army activities, with feature articles extolling his patriotism. ${ }^{23}$ He remained in Paris for 18 months in the Ordnance Department, in charge of purchasing supplies and writing contracts. His promotion to lieutenant colonel and judge advocate in

\footnotetext{
${ }^{17}$ Memorandum of March 3, 1916, quoted by Max Putzel, The Man in the Mirror: William Marion Reedy and His Magazine (Cambridge: Harvard University Press. 1963), 229.

${ }^{18}$ Anne Knish and Emanuel Morgan [i.e., Arthur Davison Ficke and Wytter Bynner], “The Spectric School of Poetry," Forum, 55, no. 1 (June 1916): 675-78.

${ }^{19}$ Ibid.

${ }^{20}$ Curtis D. MacDougall, Hoaxes (New York: Macmillan, 1940), 272.

21 "Casual Comment," Dial, 64, no. 18 (25 April 1918): 411.

22 "Soulful Spectricism Nothing But a Hoax," New York Times Magazine (June 2, 1918): 11 .

${ }^{23}$ Davenport Times, November 5, 1917. He became one of the youngest officers ever to serve as a judge advocate.
} 
1918 contrasts sharply with the antiwar activities of his literary friends, especially Floyd Dell, who stood trial for conspiracy as a writer for the Masses.

Ficke's friendship with Edna St. Vincent Millay typifies his reluctance to defy convention. They had become platonic lovers in 1912, a relationship carried on in their subsequent correspondence. Finally they met on February 19, 1918, before Ficke sailed to France. While on a trip through Europe, "Vincent" wrote to him about her memory of that encounter. "That day before you sailed,-I shall never forget it. You were the first man I ever kissed without first thinking that I should be sorry about it afterwards. There has been only one other, a boy I truly loved, in a simpler way." ${ }^{24}$ By 1923 they had become more distant friends, with only some bittersweet poems left to memorialize the affair. ${ }^{25}$

Ficke had been an early supporter of Harriet Monroe's experimental magazine, Poetry. In the summer of 1912, he commented that "the project has a fine ring to it-I rejoice to see that the Bull Moose movement is not confined to politics." ${ }^{26}$ In these early years Ficke seemed to be interested in breaking out of his traditional mold. In several essays and a published letter, he defended free verse, arguing that "the sole criterion by which any artistic theory can be judged is its success in practice." 27 He publicly defended T. S. Eliot's right to transpose a line from Meredith's sonnet as a concise quotation, not plagiarism. ${ }^{28}$ By 1916 he openly endorsed the Imagists as writers of personalized poetry, supporting the writing of Ezra Pound and Amy Lowell "as one would a theatre - willing to be entertained, but not determined to be." 29

In a slim volume of Spectric poetry issued that year, Anne Knish (alias Ficke) wrote in free verse. Some of the poems were funny with obvious wordplay; others created a momentary opening to a Surrealist dreamworld, capturing a moment in time. Opus 181 is an example of this style of poetry.

${ }^{24}$ Millay to ADF, October, 1921, Letters, p. 132. By January she had moved to Vienna and thanked him for a check. "I accept it quite humbly and gratefully in spite of all my man-sized talk. (Oh, Arthur, you are so sweet, so sweet!)," p. 144.

${ }^{25}$ A sequence of seventeen sonnets, A Hymn to Intellectual Beauty, expressed his pain and anguish over the love affair. For an explication of this sequence, see Anne Cheney, Millay in Greenwich Village (University, Alabama: University of Alabama Press, 1975), 99-101.

${ }^{26} \mathrm{ADF}$ to Harriet Monroe, August 8, 1912. Quoted in Harriet Monroe, A Poet's Life: Seventy Years in a Changing World (New York: Macmillan, 1938), 253.

27 "In Defense of Vers Libre," Little Review, 1, no. 9 (December 1914): 19-22; "Metrical Freedom and the Contemporary Poet," Dial, 58, no. 1 (January 1, 1915): 11.

28 "Imagism and Plagiarism," Dial, 58, no. 49 (9 December 1915): 560.

29 "Modern Tendencies in Poetry," North American Review, 204, no. 3 (September 1916): 439 . 
Skeptical cat,

Calm your eyes, and come to me.

For long ago, in some palmèd forest,

I too felt claws curling

Within my fingers ...

Moons wax and wane;

My eyes, too, once narrowed and widened ...

Why do you shrink back?

Come to me: let me pat you-

Come, vast-eyed one . . .

Or I will spring upon you

And with steel-hook fingers

Tear you limb from limb ....

There were twins in my cradle $\ldots{ }^{30}$

But his own poetry began to lose its experimental quality. In 1914 Ficke published a sonnet sequence that made his reputation during his lifetime. Theodore Dreiser considered Sonnets of a Portrait-Painter a critical success, writing to $\mathrm{H}$. L. Mencken that "Ficke strongly suggests Keats, Housman and lowa combined in a new, tender and delicate way." ${ }^{31}$ But his friend Floyd Dell compared these sonnets to a versified prose novel "revealing on casual examination no challenge to poetic conventions, no daring disregard of the formalities of rhyme and meter, being in fact as they are alleged to be on the cover, sonnets, they have been turned over to people who like the exquisite glazed sweetness of poetic pastries." 32

During the last 20 years of his life, critics agreed on Ficke's personal charm but felt that his poetry was too "civilized." Alfred Kreymborg considered Ficke "a bookish poet of the first order. One admires his scholarly sensibilities, his accomplished touch, the perfection of his poetic textures." ${ }^{33}$ C. A. Millspaugh summarized this criticism in his review of Ficke's The Secret. "These poems rise from mood that remembers

\footnotetext{
${ }^{30}$ Anne Knish and Emanuel Morgan [i.e., Arthur Davison Ficke and Witter Bynner], Spectra: A Book of Poetic Experiments (New York: Mitchell Kennerley, 1916), 62. See also Harry Hansen, "How a Davenporter Fooled the Entire Literary World," Davenport Times-Democrat, February 12, 1916.

${ }^{31}$ Dreiser to Mencken, July 20,1914, Letters, I, 171. A modern critic has affirmed that "Ficke's importance for American literature lies in his use of the sonnet form, for his Sonnets of a Portrait-Painter is one of the distinguished American contributions to the genre of the sonnet sequence." G. Thomas Tanselle, "Ficke's Sonnets of a PortraitPainter: Textual Problems in a Modern Poet," Yale University Library Gazette, 36, no. 1 (July 1961): 33.

32 "On Behalf of a Book of Poems," New Republic, 2, no. 25 (April 24, 1915); 309.

${ }^{33}$ Alfred Kreymborg, Our Singing Strength (New York: Coward McCann, 1929), 410.
} 
conflict, not from emotion which is the quality of conflict itself. They talk about personal struggle; they do not recreate and resolve it. The immediacy of passion is absent and there is left only its after-effect. As a result we get from the book as a whole the sweet sadness of something lost rather than the live impact, the vigorous closeness of actuality." 34

The Welsh writer John Cowper Powys, too, commented on this aspect of his friend's poetry.

The truth is, deep in your deepest heart, my friend, you have not the courage or the noble simplicity, the heroic romance, of the shameless Germanic sentiment which you find there, hanging like torn cathedral banners from the Gothic arches of your inmost soul. . . .

It is tragic to me to observe his self-controlled mask of courtly reserve quiver and tremble sometimes under the pressure of the old Nordic stirrings! . . . Without any doubt this courtly man of the world conceals, below his air of stately ceremony, the shy self-distrust of a nervous child; but it is his unhappy ability of "carrying things off" by his personal charm and his dangerous culture that prevents him ... from letting the suppressed "child" in him feel defeated, sulky, angry, desperate, which is the condition out of which volcanoes erupt. ${ }^{35}$

Ficke left Davenport permanently in 1922 with a farewell essay before the Contemporary Club and a speech for the Drama Guild of the Unitarian Church which were farewells to his parents' friends as well. ${ }^{36}$ Starting in the 1920s, Ficke (suffering from tuberculosis) and his new wife, Gladys Brown, divided their time between an estate in New York and a ranch near Santa Fe. ${ }^{37}$ Witter Bynner lived nearby, editing the Palms, which published poetry by Ficke and Marjorie Allen Seiffert.

During the last 20 years of Ficke's active life he struggled to defend traditional poetic conventions. Instead of the main stream of poetic invention and experimentation, Ficke kept to the ode, the elegy, and the sonnet sequence. As his friend Floyd Dell correctly observed, Ficke "has been in the best sense a conservative force in our poetry." ${ }^{38}$ He died in November 1945, after a long and painful bout with cancer. At the private funeral ceremony, Edna St. Vincent Millay read lines from one of his favorite poems, Milton's "Lycidas."

\footnotetext{
${ }^{34}$ C. A. Millspaugh, "Passion and Rumination," Poetry, 49, no. 5 (February 1937): 287.

${ }^{35}$ J. C. Powys, Autobiography, 611.

36 "Problem of Censorship," Contemporary Club Papers, 25 (1921-22): 69-84; Unitarian Church (Davenport) Archives.

${ }^{37}$ His beloved "Hardhack" was in Hillsdale, New York. See also A. D. Ficke, "Notes from the Diary of a Tuberculosis Patient," American Spectator. 2 (November 1934): 12-13.

${ }^{38}$ Dell, "The Ficke Wing," Measure, no. 42 (August 1924): 13.
} 